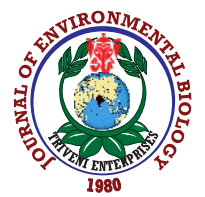

\title{
Fish community structure as an indicator of the ecological significance: A study from Ulhas River Estuary, Western coast of India
}

\author{
D.M. Lal', G.B. Sreekanth', C. Soman', K.K. Ramteke', R. Kumar ${ }^{3}$ and Z.J. Abidi ${ }^{1 *}$ \\ 'Department of Fisheries Resource Management, ICAR-Central Institute of Fisheries Education, Mumbai-400 061, India \\ ${ }^{2}$ Section of Fisheries, ICAR-Central Coastal Agricultural Research Institute, Goa-403 402, India \\ ${ }^{3}$ Department ofCrustacean Fisheries, ICAR-Central Marine Fisheries Research Institute-Research Centre, Mumbai-400 061 , India \\ *Corresponding Author Email : zjabidi@cife.edu.in
}

Paper received: 18.12 .2019

Revised received: 28.02 .2020

Accepted: 09.03 .2020

\begin{abstract}
Aim: The present study was aimed to analyze the ecological significance of Ulhas River estuary of the western coast of India using the taxonomic, functional and conservation aspects, and also to record an updated data base on the estuarine community structure.

Methodology: Ichthyo faunal diversity was assessed by experimental fishing conducted at 3 selected stations using single day dolnets of code end mesh size of $10 \mathrm{~mm}$, from September 2017 to August 2018. The diversity of fish species was recorded considering the most relevant taxonomic classification data and further supplemented by the information pertaining to ecological roles played by the individual species (using guild approach) and the IUCNconservation status.

Results: There were 105 species, belonging to 4 classes, 19 orders, 44 families and 75 genera, recorded from Ulhas River Estuary. The class: Actinopterygii was the most diverse taxa, (including 12 orders, 32 families and 55 genera) among the total ichthyofauna reported. Order Perciformes was the most representative order of the class ( 40 species, 31 genera and 17 families), followed by Decapoda (21species, 8 genera and 6 families). Based on the estuarine usefunctional guild categorization, $51.42 \%$ of the species were marine migrants, followed by amphidromous species (21.9\%). Zoobenthivores $(29.41 \%)$ was found to be the most dominant feeding guild followed by omnivores (19.6\%). Based on the IUCN Red List, $53.33 \%$ of the fish species observed from Ulhas River Estuary were categorized as "Not Evaluated", and 7\% were "Data Deficient", signifying the lack of information on biological

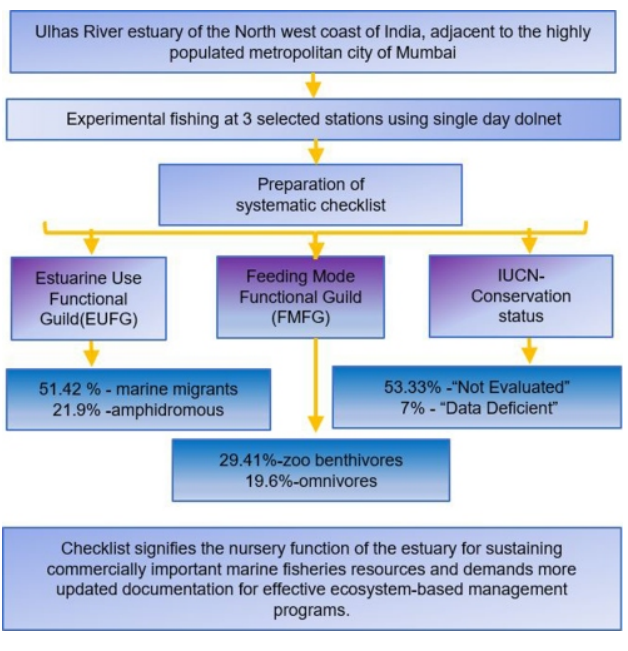
aspects of the species along Indian waters. Tenualosa toli marked its presence under threatened category (Vulnerable) from Ulhas River Estuary.
\end{abstract}

Interpretation: The abundance of marine migrants as well as the amphidromous species in the estuary signifies the use of this ecosystem for the nursery function of commercially important marine fisheries resources. Increased proportion of "Not Evaluated" and "Data Deficient" categories in the context of high level of anthropogenic stress demands for more updated documentation of the biodiversity and periodic changes in its ecological structure for formulating and implementing effective ecosystem-based management programs for such sensitive estuarine ecosystems.

Key words: Estuary, Fish community, Guild approach, Indian coast

How to cite : Lal, D.M., G.B. Sreekanth, C. Soman, K.K. Ramteke, R. Kumar and Z.J. Abidi: Fish community structure as an indicator of the ecological significance:Astudy from Ulhas River Estuary, Western coast of India. J. Environ. Biol., 41, 745-754 (2020). 


\section{Introduction}

Estuaries along India's western coast are influenced by runoff from numerous rivers and rivulets originating from the Western Ghats on one side and the tidal influx from the Arabian Sea on the other side (Sivadas et al., 2011). Apart from supporting their own resident fish community, the protected environment by the halophyte vegetation like mangrove, organic-rich mud flats and abundant food resources that provide an ideal location for most commercially important fish and shellfish to reproduce, forage and shelter in the estuarine environment (Cabral et al., 2007; McLusky and Elliott, 2004). The ecological significances coupled with the monsoon mediated fluxes makes the tropical estuarine ecosystems highly dynamic in terms of biological community structure than any other ecosystems (Ansari et al., 1995). In general, biological communities were described and classified using one or more of three sets of attributes such as; taxonomic-based entities, summarized by traditional species abundance matrices or by the size and biomass spectra of the individuals present or by the functional attributes of the recorded organisms (Nagelkerken and van der Velde, 2004; Akin et al., 2005). When these are used in combination, a huge amount of information on the community structure and functions can be portrayed.

The concept of ecological guild has been defined and worked out by different authors in a multitude of ways (Wallace, 1975; Elliot et al., 2007). However, the fundamental principle of the guild approach classifies group of species that exploit same class of environmental resources in a similar way. The guild approach increases the understanding of the use of estuaries by fishes and their interactions and connectivity with adjacent areas (Wallace, 1975). At the same time, the information on the guild structure of an ecosystem will enable the identification of the most critical species or groups which are susceptible to get affected as a result of a potential environmental impact on the ecosystem as a function of their estuarine dependence (McLusky and Elliott, 2004). For example, marine migrants are the group of species that use estuaries, especially during their juvenile stages whereas amphidromous species migrate between the sea and fresh water where their migration in neither direction is related to reproduction (McDowall, 1997).

According to Ray (2005), while studying functional attributes of an estuarine ecosystem in a management perspective, it is necessary to determine which fishes 'must' use estuaries obligatory and which therefore will be at risk if estuarine habitats are lost, compared to those which use estuaries facultatively. Therefore, the functional segregation of various species and their relative representation in various guilds yielded from the ecological guild categorization will be a potential tool to illustrate the actual role played by coastal ecosystems in maintaining biodiversity. If studied in a time series scale, It also enable to understand the potential impacts on these critical ecosystems caused by human activities and ultimately aids for the ecosystem-based management of estuaries (McLusky and
Elliott, 2004). This study was carried out in Ulhas River Estuary, situated along the western coast of India, adjacent to highly populated metropolitan city of Mumbai in Maharashtra State.

The ecosystem has been stressed by various anthropogenic activities and in this context several studies have been attempted, particularly on heavy metal and pesticide pollution, water quality and hydrological parameters (Singare et al., 2012; Menon and Mahajan, 2011; Singare, 2016), biodegradable waste accumulation (Singare, 2012) and few studies on biodiversity profiles (Lad and Patil, 2012; 2013; 2016). Thus, more studies in Ulhas River estuarine ecosystem are necessary to improve our knowledge of fish communities and their conservation. Hence, this study aims to analyze the ecological significance of Ulhas River estuary of the western coast of India using the taxonomic, functional and conservation aspects and to record the estuarine community structure. The study also attempts to depict the extent of dependency of coastal fisheries resources towards the estuaries for their various ecological functions to emphasize the necessity to protect such tropical estuarine ecosystems.

\section{Materials and Methods}

Study area: The Ulhas river estuary is situated adjacent to Mumbai, (Maharashtra) along the western coast of India. The estuary connects the Ulhas river to the Arabian Sea through Vasai creek (Fig. 1). Ulhas river estuary is a macro-tidal and well-mixed estuary, exhibiting seasonal variations in salinity attributed by the monsoon mediated freshwater influx (Rathod et al., 2002). Ulhas river estuary is characterized by semi diurnal tides, rich mangrove vegetation in the bank areas, high salinity gradient from head water to mouth, diurnal temperature variations and the land runoff carrying huge amount of sediments from its catchment area (Nikam et al., 2008).

Sampling and data collection: Ichthyo faunal diversity of the Ulhas river estuary along its true estuarine stretch (average annual Salinity 0.5-30 ppt) was analyzed from September 2017 to August 2018. Monthly sampling was carried out for an entire year to ensure representation of resident and seasonal migrant species in the estuary. Experimental fishing was done at 3 selected stations, care was taken to consider different ecological conditions between the selected stations. Station 1 was sheltered area surrounded by rich mangrove vegetation, where the estuarine area narrows down to a small creak due the presence of small island (Panju Island), while Station 2 was more or less open waters adjacent to the estuarine mouth, where easy transit of the fishes between the marine waters were expected. Station 3 was close to the Vasai-railway bridge, which is comparatively disturbed and characterized by the adjacency of residential area. Experimental fishing was carried out using dolnets of cod end mesh size $10 \mathrm{~mm}$ and total length of $30 \mathrm{~m}$. For the present study, the dolnets are set against the tidal flow, moored at spikes that are fixed at identified stations and operated for a period of 3 to 4 hrs during daytime according to the tidal pattern in the area. The main 
webbing of net consisted of four segments, locally known as Chirate (Mouth), Katra, Mazwala and Khola (cod-end), with large meshes at the mouth and smaller meshes towards the cod-end. At mouth opening, the length and width of the net were $10 \mathrm{~m}$ and 4 $m$, respectively. Finfishes and shellfishes were identified up to species level in the field to the extent as possible. Whereas species with ambiguity were brought to the laboratory for detailed identification. Taxonomic identification was performed based on the relevant taxonomic keys (Fischer and Bianchi, 1984; Bianchi, 1985; Psomadakis et al., 2015).

The taxonomic arrangement (nomenclature and classification) follow WORMS (World Register of Marine Species) data base (2019), while the conservation status was based on the Red List of Threatened Species, International Union for Conservation of Nature (IUCN,2019). The ecological roles played by each individual species were qualitatively identified and listed following a guild approach developed by Elliot et al. (2007). By considering the seasonal and spatial occurrence of species and their use of estuarine ecosystem as nursery-feeding or refuge areas and migration routes, species were assigned into 10 broad Estuarine Use Functional Guilds (EUFG) (Elliot et al., 2007), such as: Marine stragglers (MS), Marine migrants (MM), Estuarine species (ES), Anadromous (AN), Semi-anadromous (SA), Catadromous (CA), Semi-catadromous (SC), Amphidromous (AM), Freshwater migrants (FM) and Freshwater stragglers (FS). Likewise, fish species that utilize similar food resources were aggregated and categorized by feeding mode Functional Guilds (FMFG) (Elliott et al., 2007). The feeding niche of each species was identified by direct qualitative estimation of the gut contents to the possible extent and the rest were obtained from the Fish Base (Froese and Pauly, 2019). The Feeding Functional Guilds (FFG) proposed here identifies seven broad categories: Detritivore(DV), Herbivore (HV), Omnivore (OV), Zooplanktivore (ZP), Zoobenthivore (ZB), Piscivore (PV) and miscellaneous/ opportunistfeeders (OP). The assignment criteria of various guilds are listed in supplementary Table1. and 2. The format given by Nelson and Martin (1992) and González et al. (2018) was adopted for the tabulation of compiled information.

\section{Results and Discussion}

The information on the fish communities and the trophic guild structure in response to environmental factors have been used to make long-term comparisons in variations occurring in estuarine biological communities (Livingston, 1976) and also to assess environmental quality (Bechtel and Copeland, 1970). The systematic list of fish community of Ulhas river estuary including the guild structure and the conservation status are depicted in Table 1. The estuarine Fish community is composed of 105 species, belonging to 4 classes, 19 orders, 44 families and 75 genera. The class: Actinopterygii was the most diverse class representing $73.33 \%$ (including 12 orders, 32 families and 55 genera) of the total ichthyo fauna reported. Order Perciformes was the most representative order (40 species, 31 genera 17 families), followed by Decapoda (21species, 8 genera and 6 families) and
Clupeiformes (15 species, 7 genera and 3 families) (Fig. 2). The three perciform families such as Sciaenidae ( 5 genera 8 species), Carangidae ( 6 genera, 7 species) and Gobiidae (4 genera, 5 species) alone contributed around $25 \%$ of the overalll chthyo faunal diversity in the Ulhas river estuary (Fig. 3). The fish diversity reported for Ulhas River Estuarine ecosystem is greater than that reported by the previous studies in the area. According to the available records, the decapod crustacean diversity of the Ulhas river estuary consists of 6 species of crabs and 10 species of shrimps (Lad and Patil, 2012). While the finfish diversity consists of 53 species belonging to 23 families and 6 orders (Lad and Patil, 2013). Thus, the fish community structure described in this study showed an increase in diversity of species from Ulhas river estuary. This represents $5.2 \%$ of the total marine and estuarine fish species known from the country (NBFGR, 2018).

The high fish diversity reported from the estuarine-coastal areas is due to variety of young and adult marine fish species that enter these biotopes, following seasonal patterns in their occurrence and biomass (González-Acosta et al., 2015). Thus, diverse fish species take advantage of the availability of suitable habitats with soft substrates and submerged vegetation (Mangrove biotopes), as well as the area's favorable hydrological conditions (Díaz-Ruiz et al., 2006; González-Acosta et al., 2018). The dominance of class Actinopterygii and predominance of Perciformes over other orders of teleost fishes (e.g., Clupeiformes, Pleuronectiformes, Siluriformes, Anguilliformes and Tetraodontiformes) are in agreement with the community structure of similar coastal lagoons and estuaries in the tropical context (Das et al., 2018; Sreekanth et al., 2018). The limited presence of Elasmobranchs in the estuarine habitat could be due to the absence of suitable soft bottom substrates in the area as well as protective nature of the environment offered by the mangrove patches, restricting entry of such top predators into these ecosystems (Elliott et al., 2007).

Among the total species recorded from the estuary, $51.4 \%(n=54)$ were marine migrants (MM), which usually spawn in sea and often enter estuaries in large numbers, particularly as juveniles. The underlying premise of most studies that examine nursery-role concepts is that some nearshore, juvenile habitats contribute disproportionally to the production of individuals that recruit to adult populations (Beck et al., 2001). The Ulhas river estuary is characterized by the presence of considerable mangrove vegetation along its banks (Rathod et al.,2002). Also, the Mumbai coast alone harbours $66 \mathrm{~km}^{2}$ of mangroves, which accounts $21.7 \%$ of the mangrove cover of the state of Maharashtra (Kantharajan et al., 2018). Therefore, the dominance of marine migrants clearly indicates nursery function of the ecosystem for commercially important marine fisheries resources along the north eastern Arabian Sea. The second major estuarine use guild was that of Amphidromous species (AM) that contributed $21.9 \%(n=23)$ to the total species diversity. A total of nine anadromous and one semi anadromous species were also recorded that undergo their greatest growth at sea and migrate to river and estuarine ecosystems, respectively, where spawning 
Table 1: Annotated systematic list of fishes of Ulhas River Estuary, including the ecological guild structure and conservation status

\begin{tabular}{|c|c|c|c|}
\hline Taxon & *EUFG & *FFG & IUCN category \\
\hline $\begin{array}{l}\text { PHYLUM: Chordata } \\
\text { CLASS: Elasmobranchii } \\
\text { ORDER: Orectolobiformes } \\
\text { FAMILY: Hemiscylliidae }\end{array}$ & & & \\
\hline $\begin{array}{l}\text { Chiloscyllium griseum Müller \& Henle, } 1838 \\
\text { ORDER: Myliobatiformes } \\
\text { FAMILY: Dasyatidae }\end{array}$ & MS & ZB & NT \\
\hline $\begin{array}{l}\text { Brevitrygon imbricata (Bloch \& Schneider, 1801) } \\
\text { CLASS: Actinopterygii } \\
\text { ORDER: Elopiformes } \\
\text { FAMILY: Megalopidae }\end{array}$ & AM & ZB & DD \\
\hline $\begin{array}{l}\text { Megalops cyprinoides (Broussonet, 1782) } \\
\text { ORDER: Clupeiformes } \\
\text { FAMILY: Clupeidae }\end{array}$ & AM & PV & DD \\
\hline Nematalosa nasus (Bloch, 1795) & AN & ZP & LC \\
\hline Anodontostoma chacunda (Hamilton, 1822) & AN & ZP & NE \\
\hline Sardinella longiceps Valenciennes, 1847 & MM & $\mathrm{HV}$ & LC \\
\hline Sardinella albella (Valenciennes, 1847) & MM & ZP & LC \\
\hline Sardinella gibbosa (Bleeker, 1849) & MM & ZP & LC \\
\hline Tenualosa toli (Valenciennes, 1847) & SA & ZP & VU \\
\hline Escualosa thoracata (Valenciennes, 1847) & MM & ZP & LC \\
\hline \multicolumn{4}{|l|}{ FAMILY: Engraulidae } \\
\hline Thryssa dussumieri (Valenciennes, 1848) & MM & ZP & LC \\
\hline Thryssa hamiltonii Gray, 1835 & AM & ZP & LC \\
\hline Coilia dussumieri Valenciennes, 1848 & AM & ZP & NE \\
\hline Thryssa setirostris (Broussonet, 1782) & MM & ZP & LC \\
\hline Stolephorus indicus (van Hasselt, 1823) & MM & $\mathrm{ZP}$ & LC \\
\hline \multicolumn{4}{|l|}{ FAMILY : Pristigasteridae } \\
\hline Pellona ditchela Valenciennes, 1847 & AN & ZP & LC \\
\hline Opisthopterus tardoore (Cuvier, 1829) & AM & $\mathrm{ZP}$ & LC \\
\hline Ilisha filigera (Valenciennes, 1847) & AN & ZP & DD \\
\hline \multicolumn{4}{|l|}{ ORDER: Anguilliformes } \\
\hline Pisodonophis boro (Hamilton, 1822) & AN & PV & LC \\
\hline \multicolumn{4}{|l|}{ ORDER: Siluriformes } \\
\hline Arius maculatus (Thunberg, 1792) & AM & ZB & NE \\
\hline Nemapteryx caelata (Valenciennes, 1840) & AM & ZB & NE \\
\hline Osteogeneiosus militaris (Linnaeus, 1758) & AM & ZB & NE \\
\hline \multicolumn{4}{|l|}{ FAMILY: Bagridae } \\
\hline Sperata seenghala (Sykes, 1839) & FM & ZB & LC \\
\hline \multicolumn{4}{|l|}{ FAMILY: Plotosidae } \\
\hline $\begin{array}{l}\text { Plotosus lineatus (Thunberg, 1787) } \\
\text { ORDER: Mugiliformes } \\
\text { FAMILY: Mugilidae }\end{array}$ & AM & ZB & NE \\
\hline Osteomugil cunnesius (Valenciennes, 1836) & $\mathrm{CA}$ & DV & NE \\
\hline Mugil cephalus Linnaeus, 1758 & $\mathrm{CA}$ & DV & LC \\
\hline \multicolumn{4}{|l|}{ ORDER: Gadiformes } \\
\hline \multicolumn{4}{|l|}{ FAMILY: Bregmacerotidae } \\
\hline Bregmaceros mcclellandi Thompson, 1840 & MM & ZP & $\mathrm{NE}$ \\
\hline \multicolumn{4}{|l|}{ ORDER: Perciformes } \\
\hline Boleophthalmus dussumieri Valenciennes, 1837 & AM & DV & LC \\
\hline
\end{tabular}




\begin{tabular}{|c|c|c|c|}
\hline Taxon & *EUFG & ${ }^{*} \mathrm{FFG}$ & IUCN category \\
\hline Boleophthalmus boddarti (Pallas, 1770) & AM & DV & LC \\
\hline Parachaeturichthys polynema (Bleeker, 1853) & MS & OV & NE \\
\hline Trypauchen vagina (Bloch \& Schneider, 1801) & AM & OV & NE \\
\hline Odontamblyopus roseus (Valenciennes, 1837) & MM & OV & NE \\
\hline $\begin{array}{l}\text { Butis butis (Hamilton, 1822) } \\
\text { FAMILY: Sillaginidae }\end{array}$ & ES & $\mathrm{OP}$ & LC \\
\hline $\begin{array}{l}\text { Sillago sihama (Forsskål, 1775) } \\
\text { FAMILY: Leiognathidae }\end{array}$ & AM & ZB & LC \\
\hline Eubleekeria splendens (Cuvier, 1829) & MM & ZB & LC \\
\hline $\begin{array}{l}\text { Secutor insidiator (Bloch, 1787) } \\
\text { FAMILY: Ambassidae }\end{array}$ & AM & ZB & NE \\
\hline $\begin{array}{l}\text { Ambassis ambassis (Lacepède, 1802) } \\
\text { FAMILY: Apogonidae }\end{array}$ & ES & $\mathrm{OP}$ & LC \\
\hline $\begin{array}{l}\text { Ostorhinchus fasciatus (White, 1790) } \\
\text { FAMILY: Scatophagidae }\end{array}$ & MS & $\mathrm{OP}$ & NE \\
\hline $\begin{array}{l}\text { Scatophagus argus (Linnaeus, 1766) } \\
\text { FAMILY: Scombridae }\end{array}$ & ES & OV & LC \\
\hline Rastrelliger kanagurta (Cuvier, 1816) & MS & ZP & $\mathrm{DD}$ \\
\hline $\begin{array}{l}\text { Scomberomorus guttatus (Bloch \& Schneider, 1801) } \\
\text { FAMILY: Stromateidae }\end{array}$ & MS & PV & DD \\
\hline Pampus argenteus (Euphrasen, 1788) & MM & ZB & NE \\
\hline $\begin{array}{l}\text { Pampus chinensis (Euphrasen, 1788) } \\
\text { FAMILY: Gerreidae }\end{array}$ & MM & ZB & NE \\
\hline $\begin{array}{l}\text { Gerres filamentosus Cuvier, } 1829 \\
\text { FAMILY: Sciaenidae }\end{array}$ & AM & ZB & NE \\
\hline Johnius macrorhynus (Lal Mohan, 1976) & MM & ZB & NE \\
\hline Johnius belangerii (Cuvier, 1830) & AM & ZB & NE \\
\hline Johnius dussumieri (Cuvier, 1830) & MM & ZB & NE \\
\hline Johnius glaucus (Day, 1876) & MM & ZB & NE \\
\hline Johnius borneensis (Bleeker, 1851) & MM & PV & $\mathrm{NE}$ \\
\hline Otolithes cuvieri Trewavas, 1974 & MM & PV & NE \\
\hline Otolithoides biauritus (Cantor, 1849) & AM & ZB & NE \\
\hline $\begin{array}{l}\text { Protonibea diacanthus (Lacepède, 1802) } \\
\text { FAMILY: Carangidae }\end{array}$ & MM & ZB & NE \\
\hline Alepes kleinii (Bloch, 1793) & MM & PV & LC \\
\hline Alepes djedaba (Forsskål, 1775) & MM & PV & LC \\
\hline Megalaspis cordyla (Linnaeus, 1758) & MM & PV & LC \\
\hline Atule mate (Cuvier, 1833) & MM & PV & LC \\
\hline Decapterus russelli (Rüppell, 1830) & MM & PV & LC \\
\hline Atropus atropos (Bloch \& Schneider, 1801) & MM & ZB & LC \\
\hline Parastromateus niger (Bloch, 1795) & AM & ZP & LC \\
\hline $\begin{array}{l}\text { Alepes djedaba (Forsskål, 1775) } \\
\text { FAMUYY. Terapontidae }\end{array}$ & MM & PV & LC \\
\hline Terapon jarbua (Forsskål, 1775) & $\mathrm{CA}$ & $\mathrm{OP}$ & LC \\
\hline $\begin{array}{l}\text { Terapon theraps (Cuvier, 1829) } \\
\text { FAMILY: Polynemidae }\end{array}$ & $\mathrm{AM}$ & $\mathrm{OP}$ & LC \\
\hline Leptomelanosoma indicum (Shaw, 1804) & AM & ZB & NE \\
\hline Filimanus heptadactyla (Cuvier, 1829) & MM & ZB & NE \\
\hline $\begin{array}{l}\text { Eleutheronema tetradactylum (Shaw, 1804) } \\
\text { FAMILY: Trichiuridae }\end{array}$ & AM & ZB & NE \\
\hline Eupleurogrammus muticus (Gray, 1831) & MM & PV & NE \\
\hline Lepturacanthus savala (Cuvier, 1829) & MM & PV & $\mathrm{NE}$ \\
\hline $\begin{array}{l}\text { Trichiurus lepturus Linnaeus, } 1758 \\
\text { FAMILY: Latidae }\end{array}$ & MM & PV & LC \\
\hline $\begin{array}{l}\text { Lates calcarifer (Bloch, 1790) } \\
\text { FAMILY: Lactariidae }\end{array}$ & SC & PV & $\mathrm{NE}$ \\
\hline
\end{tabular}




\begin{tabular}{|c|c|c|c|}
\hline Taxon & ${ }^{*}$ EUFG & *FFG & IUCN category \\
\hline $\begin{array}{l}\text { Lactarius lactarius (Bloch \& Schneider, 1801) } \\
\text { FAMILY: Lutjanidae }\end{array}$ & MS & ZB & NE \\
\hline $\begin{array}{l}\text { Lutjanus johni (Bloch, 1792) } \\
\text { FAMILY: Sphyraenidae }\end{array}$ & MM & PV & LC \\
\hline $\begin{array}{l}\text { Sphyraena jello Cuvier, } 1829 \\
\text { ORDER: Pleuronectiformes } \\
\text { FAMILY: Cynoglossidae }\end{array}$ & MS & PV & NE \\
\hline $\begin{array}{l}\text { Cynoglossus arel (Bloch \& Schneider, 1801) } \\
\text { ORDER: Aulopiformes } \\
\text { FAMILY: Synodontidae }\end{array}$ & MM & ZB & NE \\
\hline $\begin{array}{l}\text { Harpadon nehereus (Hamilton, 1822) } \\
\text { ORDER: Scorpaeniformes } \\
\text { FAMILY: Platycephalidae }\end{array}$ & MM & $\mathrm{OP}$ & NT \\
\hline $\begin{array}{l}\text { Platycephalus indicus (Linnaeus, 1758) } \\
\text { ORDER: Batrachoidiformes } \\
\text { FAMILY: Batrachoididae }\end{array}$ & AM & ZB & DD \\
\hline $\begin{array}{l}\text { Allenbatrachus grunniens (Linnaeus, 1758) } \\
\text { ORDER:Tetraodontiformes } \\
\text { FAMILY: Tetraodontidae }\end{array}$ & AM & ZB & NE \\
\hline $\begin{array}{l}\text { Takifugu oblongus (Bloch, 1786) } \\
\text { Lagocephalus lunaris (Bloch \& Schneider, 1801) } \\
\text { PHYLUM: Arthropoda } \\
\text { CLASS: Malacostraca } \\
\text { ORDER: Decapoda } \\
\text { FAMILY: Lysmatidae }\end{array}$ & $\begin{array}{l}\text { MM } \\
\text { MM }\end{array}$ & $\begin{array}{l}\mathrm{ZB} \\
\mathrm{ZB}\end{array}$ & $\begin{array}{l}\mathrm{LC} \\
\mathrm{LC}\end{array}$ \\
\hline $\begin{array}{l}\text { Exhippolysmata ensirostris ensirostris (Kemp, 1914) } \\
\text { FAMILY: Palaemonidae }\end{array}$ & MM & OV & NE \\
\hline Exopalaemon styliferus (H. Milne Edwards, 1840 ) & MM & OV & $\mathrm{NE}$ \\
\hline Nematopalaemon tenuipes (Henderson, 1893) & MM & OV & NE \\
\hline $\begin{array}{l}\text { Macrobrachium rosenbergii (de Man, 1879) } \\
\text { FAMILY: Penaeidae }\end{array}$ & FM & OV & NE \\
\hline Penaeus indicus H. Milne Edwards, 1837 & MM & OV & NE \\
\hline Metapenaeus brevicornis (H. Milne Edwards, 1837) & MM & OV & NE \\
\hline Metapenaeus affinis (H. Milne Edwards, 1837) & MM & OV & $\mathrm{NE}$ \\
\hline Parapenaeopsis sculptilis (Heller, 1862) & MM & OV & NE \\
\hline Metapenaeus monoceros (Fabricius, 1798) & MM & OV & NE \\
\hline $\begin{array}{l}\text { Parapenaeopsis stylifera (H. Milne Edwards, 1837) } \\
\text { FAMILY: Alpheidae }\end{array}$ & MM & OV & NE \\
\hline $\begin{array}{l}\text { Alpheus digitalis De Haan, } 1844 \\
\text { FAMILY: Sergestidae }\end{array}$ & $\mathrm{FM}$ & OV & NE \\
\hline Acetes indicus H. Milne Edwards, 1830 & MM & OV & NE \\
\hline $\begin{array}{l}\text { Acetes johni (Nataraj, 1949) } \\
\text { FAMILY: Portunidae }\end{array}$ & MM & OV & NE \\
\hline Charybdis (Charybdis) lucifera (Fabricius, 1798) & MM & OV & NE \\
\hline Charybdis (Charybdis) orientalis Dana, 1852 & MM & OV & NE \\
\hline Charybdis (Charybdis) callianassa (Herbst, 1789) & MM & OV & NE \\
\hline Scylla tranquebarica (Fabricius, 1798) & ES & OV & NE \\
\hline Scylla serrata (Forskål, 1775) & ES & OV & NE \\
\hline Portunus (Portunus) pelagicus (Linnaeus, 1758) & MM & OV & NE \\
\hline $\begin{array}{l}\text { Portunus (Portunus) sanguinolentus (Herbst, 1783) } \\
\text { ORDER: Stomatopoda } \\
\text { FAMILY: Squillidae }\end{array}$ & MM & OV & NE \\
\hline Harpiosquilla harpax (de Haan, 1844) & MM & OV & NE \\
\hline $\begin{array}{l}\text { Miyakella nepa (Latreille in Latreille, Le Peletier, Serville \& Guérin, 1828) } \\
\text { PHYLUM: Mollusca } \\
\text { CLASS: Cephalopoda }\end{array}$ & MM & OV & NE \\
\hline
\end{tabular}




\begin{tabular}{|c|c|c|c|}
\hline Taxon & *EUFG & *FFG & IUCN category \\
\hline $\begin{array}{l}\text { ORDER: Sepiida } \\
\text { FAMILY: Sepiidae }\end{array}$ & & & \\
\hline $\begin{array}{l}\text { Sepiella inermis (Van Hasselt [in Férussac \& d'Orbigny], 1835) } \\
\text { ORDER: Myopsida } \\
\text { FAMILY: Loliginidae }\end{array}$ & MM & PV & DD \\
\hline $\begin{array}{l}\text { Uroteuthis (Photololigo) duvaucelii (d'Orbigny [in Férussac \& d'Orbigny], 1835) } \\
\text { ORDER: Octopoda } \\
\text { FAMILY: Octopodidae }\end{array}$ & MS & PV & $\mathrm{DD}$ \\
\hline Cistopus indicus (Rapp, 1835) & MS & PV & LC \\
\hline
\end{tabular}

( ${ }^{*}$ EUFG- Estuarine Use Functional Guild; FFG- Feeding Functional Guild; MS- Marine stragglers; MM- Marine migrants; ES- Estuarine species; ANAnadromous; SA- Semi-anadromous; CA- Catadromous; SC- Semi-catadromous; AM- Amphidromous; FM- Freshwater migrants; FS- Freshwater stragglers; DV-Detritivore; HV- Herbivore; OV-Omnivore; ZP-Zooplanktivore; ZB-Zoobenthivore; PV-Piscivore; OP -miscellaneous/ opportunist feeders; VU-Vulnerable; NT-Near Threatened; LC-Least Concern; DD-Data Deficient; NE-Not Evaluated)

takes place subsequently. In addition, three catadromous (CA), one semi catadromous (SC) and one freshwater migrant (FM) species were accounted for the guild structure of Ulhas river estuary. Estuarine residents constituted $4.5 \%$ of the total species observed in Ulhas river estuary. Amphidromous species are those which migrate between freshwater and the sea, but the movements are not related to breeding migrations (McDowall, 1997). Probably, the abundance of fish food organisms in the estuarine environment might be the reason that attracts the amphidromous as well as marine stragglers (8.5\%) in the ecosystem. Estuaries and wetlands have been identified as nurseries in part because they export vast quantities of carbon, nitrogen and phosphorus to coastal food webs (Childers et al.,
2005). Export of these nutrients are channelled through direct transfer of animal biomass via movement of individuals, predationor out-welling of dissolved and particulate organic matter (Childers et al., 2005). As per studies, a considerable load of municipal sewage from Thane city mainly attributes for a high degree of organic nutrient loading and supplement to high productivity in the area (Patil and Ingle, 2016).

As far as feeding guild structure is concerned, zoobenthivores $(29.41 \% ; n=30)$ and omnivores $(25.49 \% ; n=26)$ contributed the major proportion of fish species present in Ulhas river estuary. The zoobenthivore consists of fishes that feed on organisms associated with the substratum including animals that

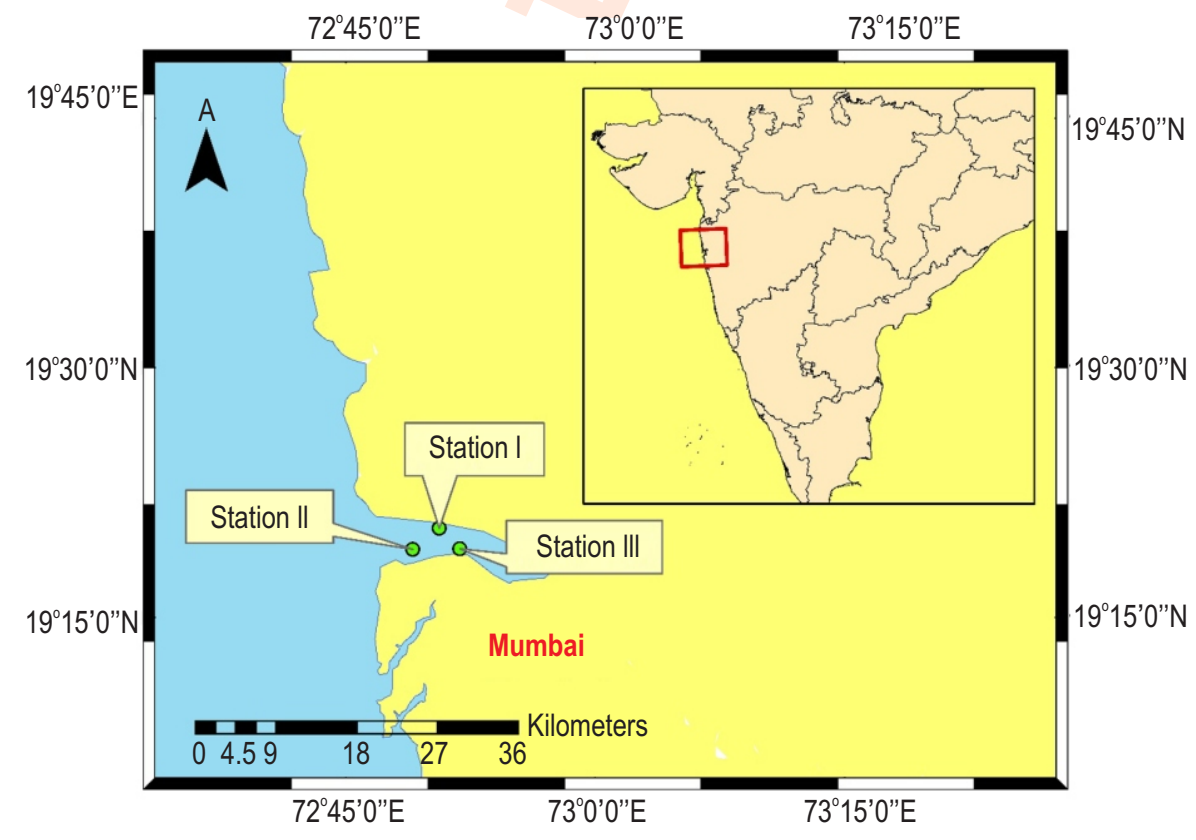

Fig. 1: Study area in Ulhas River Estuary located along the N-West coast of India. 


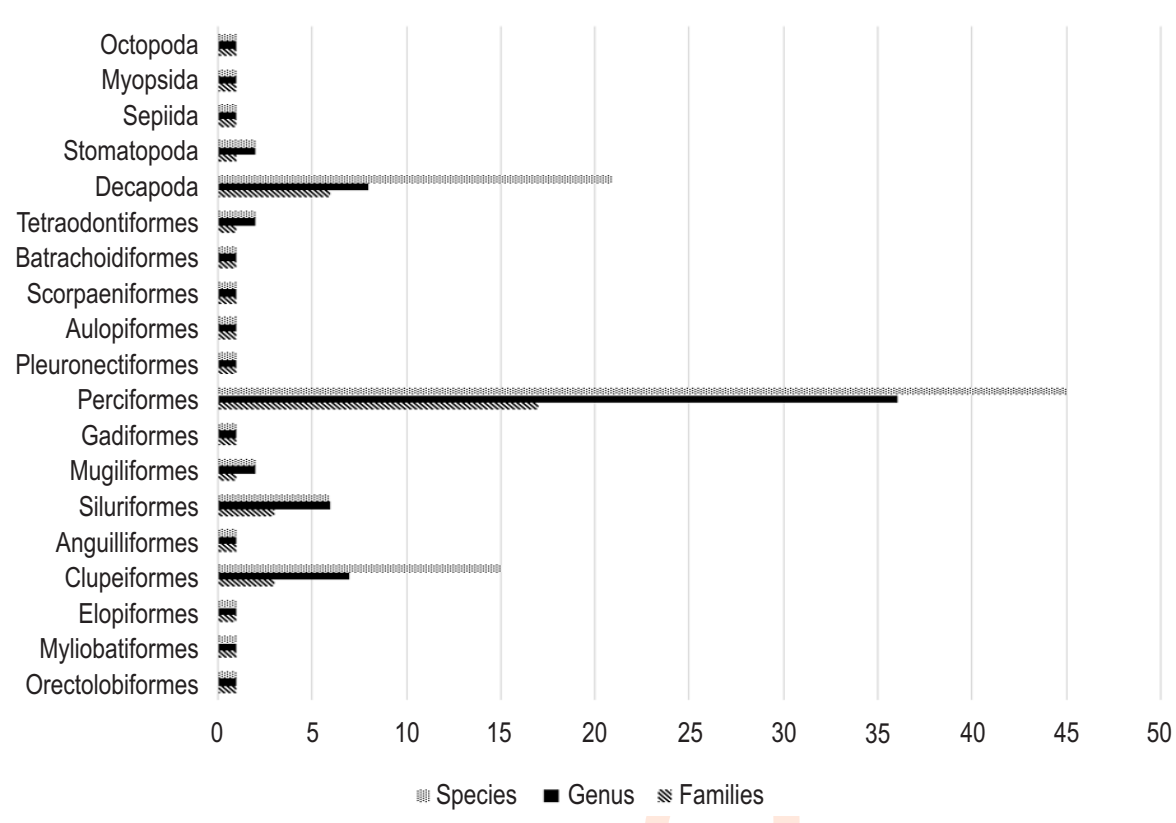

Fig. 2: Families, genera and species by order of Ulhas River Estuary.

live in the sediment (infauna), on the sediment (epifauna) or immediately above the sediment (Elliot et al., 2007). Deshmukh (2002) has reported the existence of good amount of detritus in the shallow coastal waters, several times than that along the off Mumbai waters in the north west coast of India, which supports the abundance of benthos and benthic invertebrates in the region.
This includes species like Acetes indicus (paste shrimp), one of the highly significant food item of most of the commercial fin fish species (belonging to the dominant groups like Sciaenids, Carangids, Bombay duck, etc.) in the north western coast of India (Jaiswar and Chakraborty, 2005). Hence, the abundance of zoobenthivores is a clear indication of foraging aggregation of these

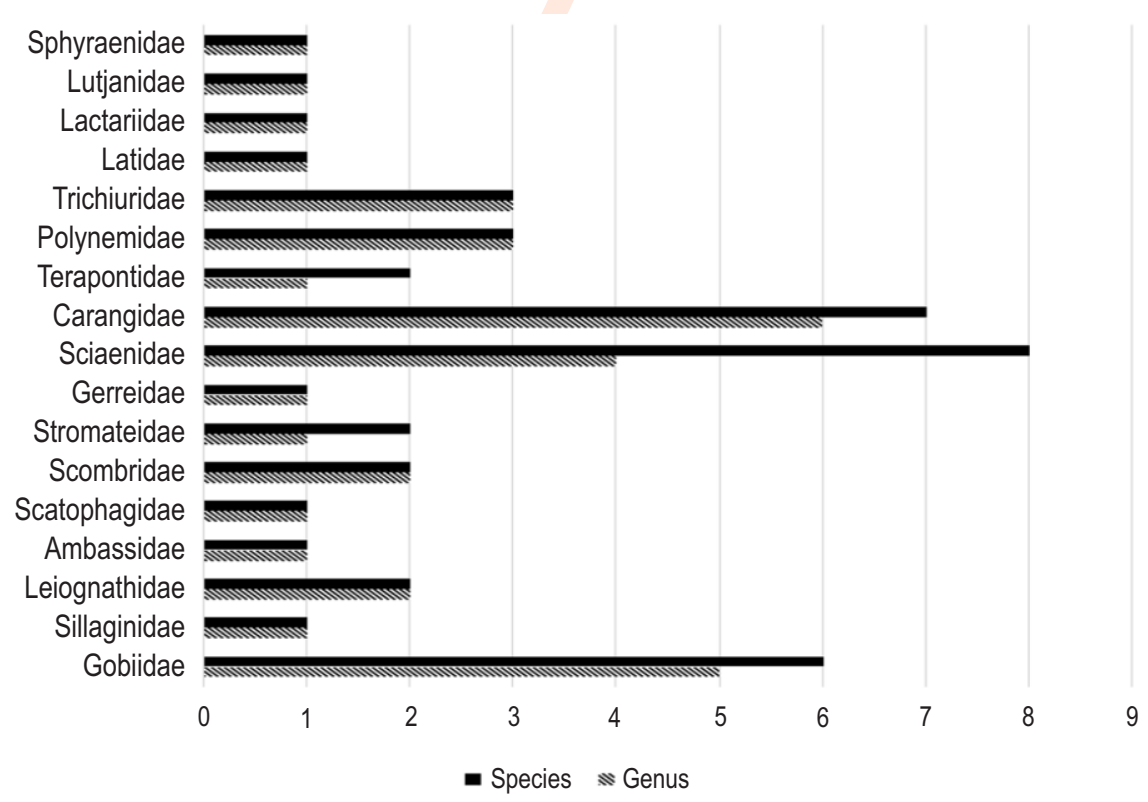

Fig. 3: Genera and species representative of the order Perciformes Ulhas River Estuary. 
species in the ecosystem. Piscivores (19\%) and zooplanktivores (17\%) have also contributed a notable proportion of feeding guilds in Ulhas river estuary. This shows the abundance of secondary and territory consumer groups over herbivores and detritivores, which together accounts merely about $4 \%$ of the total species recorded.

Since there is lack of corresponding information on biological aspects, $53.3 \%$ of fish species observed from Ulhas River Estuary were categorized based on the IUCN Red List of Threatened Species as "Not Evaluated", and 7\% were "Data Deficient". On the other hand, $36.1 \%$ of the species were listed as "Least Concern". Tenualosa toli was the single species reported under the threatened category (Vulnerable-VU). The bamboo shark, Chiloscyllium griseum and the Bombay duck, Harpadon nehereus were the near-threatened species among the recorded species. The presence of threatened and near-threatened groups in the estuary points towards a big concern for the near future when the present fishing scenario in the estuary is considered. In Ulhas river estuary, the major fishing gear in operation is single day dolnet (Locally known as bokshi jal/ Ghana khola), with a codend mesh of $5 \mathrm{~mm}$ to $10 \mathrm{~mm}$. Hence the non-selective fishing activities along with the pollution load have a great potential to cause apparent damage to the biodiversity and community structure with a major threat to the juveniles as well as the threatened species (Singare et al., 2012; Menon and Mahajan, 2011; Singhare, 2016). As a whole, this study quotes a caution for managing this valuable ecosystem and its biodiversity in the context of its remarkable functions as nursery, refuge habitat and migratory pathway as indicated by representing of $51.4 \%$ of marine migrant species and $21.9 \%$ of amphidromous species that visit the estuary annually.

In conclusion, the present study emphasizes high magnitude of dependency on coastal fisheries resources towards the estuarine habitat. Further, detailed information on the community structure of Ulhas River Estuary depicted in this study, based on the guild approach, will potentially advance our understanding of functional community segregation in estuaries of the Indian context. We encourage more studies that quantify the fish assemblage structure of the estuaries in wide regional scales that will facilitate rigorous comparisons between the characteristics of estuarine communities that enable the formulation of more reliable ecosystem-based management plans for this sensitive transitional ecosystem with high fisheries potential.

\section{Acknowledgments}

The authors gratefully acknowledge the Director ICARCIFE Mumbai for providing necessary facilities to carry out this work. The authors are also grateful to the Director of ICARCMFRI, Kochi, the SIC, ICAR-CMFRI Regional Research Centre, Mumbai and the Director, ICAR- CCARI, Goa for their constant support and guidance in accomplishing this work. The authors express their heartfelt thanks to the fishermen along Naigaon, Vasai for their kind co-operation with the fishing experiments. Funding for this study was provided by ICAR-CIFE
Mumbai, India in the form of ICAR research fellowship to one of the researchers Ms. Dhanya M. Lal.

\section{References}

Akin, S., E. Buham, K.O. Winemuller and H. Yilmaz: Fish assemblage structure of Koycegiz Lagoon Estuary, Turkey: Spatial and temporal distribution patterns in relation to environmental variation. Estuar. Coast. Shelf Sci., 64, 671-684 (2005)

Anonymous: Annual Report 2017-18, ICAR-National Bureau of Fish Genetic Resources, Lucknow, India (2018).

Ansari, Z.A., A. Chatterji, B.S. Ingole, R.A. Sreepada, C.U. Rivonkar and A.H. Parulekar: Community structure and seasonal variation of an inshore demersal fish community at Goa, west coast of India. Estuar. Coast. Shelf Sci., 41, 593-610 (1995).

Bechtel, T.J. and B.J. Copeland: Fish species diversity indices as indicators of pollution in Galveston Bay, Texas (1970).

Beck, M.W., K.L. Heck, K.W. Able, D.L. Childers, D.B. Eggleston, B.M. Gillanders and R.J. Orth: The identification, conservation and management of estuarine and marine nurseries for fish and invertebrates: A better understanding of the habitats that serve as nurseries for marine species and the factors that create sitespecific variability in nursery quality will improve conservation and management of these areas. Bioscience, 51,633-641 (2001).

Bianchi, G.: Field guide to the commercial marine and brackish-water species of Pakistan, FAO (1985).

Cabral, H.N., R. Vasconcelos, C. Vinagre, S. França, V. Fonseca, A. Maia and V. Freitas: Relative importance of estuarine flatfish nurseries along the Portuguese coast. J. Sea Res., 57, 209-217(2007).

Childers, A.R., T.E. Whitledge and D.A. Stockwell: Seasonal and interannual variability in the distribution of nutrients and chlorophyll a across the Gulf of Alaska shelf: 1998-2000. Deep Sea Research Part II: Topical Studies in Oceanography, 52, 193-216 (2005).

Das, I., S. Hazra, S. Das, S. Giri, A. Chanda, S. Maity and S. Ghosh: Trophic-level modelling of the coastal waters of the northern Bay of Bengal, West Bengal, India. Fisheries Science, 84, 995-1008 (2018).

Deshmukh, V.D.: Biology of Acetes indicus milne edwards in Bombay waters. Indian J. Fish., 49, 379-388 (2002).

Díaz-Ruiz, S., A. Aguirre-León and E. Cano-Quiroga: Evaluación ecológica de las comunidades de peces en dos sistemas lagunares estuarinos del sur de Chiapas, México. Hidrobiológica, $16,197-210(2006)$

Elliott, M., A.K. Whitfield, I.C. Potter, S.J. Blaber, D.P. Cyrus, F.G. Nordlie and T.D. Harrison: The guild approach to categorizing estuarine fish assemblages: Aglobal review. Fish Fishe., 8, 241-268 (2007).

Fischer, W. and G. Bianchi: FAO species identification sheets for fishery purposes: Western Indian Ocean (Fishing Area 51). Alphabetical index of scientific names and vernacular names V 1:-6 (1984).

Froese, R. and D. Pauly: Fish Base. World Wide Web electronic publication. www.fishbase.org, version (08/2019) (2019).

González-Acosta, A.F., J.A. Rabadán-Sotelo, G. Ruiz-Campos, F. Del Moral-Flores and J.M. Borges-Souza: A systematic list of fishes from an insular mangrove ecosystem in the Gulf of California. The arid mangroves from Baja California Peninsula, 1, 81-92 (2015).

González-Acosta, A.F., R. Rodiles-Hernández and A.A. González-Díaz: Checklist of the marine and estuarine fishes of Chiapas, Mexico. Marine Biodiversity, 48,1439-1454 (2018).

IUCN 2019: The IUCN Red List of Threatened Species.Version 2019-2. http://www.iucnredlist.org. Downloaded on 18 July 2019.

Jaiswar, A. K. and S. K. Chakraborty: Acetes, the preferred food of fishes along the north-west coast of India. Indian J. Fishe., 52, 215-219 (2005). 
Kantharajan, G., P.K. Pandey, P. Krishnan, P. Ragavan, J.J.J. Jeevamani, R. Purvaja and R. Ramesh: Vegetative structure and species composition of mangroves along the Mumbai coast, Maharashtra, India. Region. Stud. Mar. Sci., 19, 1-8 (2018).

Lad, D. and S. Patil: Assessment of fish diversity in the estuarine area of Bhayander and Naigaon, Thane (MS) India. Sci. Res. Repo., 3, 229-232 (2012).

Lad, D. and S. Patil: Diversity of Decapodan Fauna Along the Estuarine Area of Bhayander and Naigaon, Thane, Maharashtra, India. In: Proceedings of National seminar on Biodiversity and Conservation of Coastal and Marine Ecosystems of India, pp. 43-45 (2013).

Lad, D. and S. Patil: Diversity of intertidal meiobenthos from estuary of Bhayander and Naigaon, Thane, Maharashtra, India. Int. J. Sci. Res., 5, 245-246 (2016).

Livingston, R.J.: Diurnal and seasonal fluctuations of organisms in a north Florida estuary. Estuarine Coastal Marine Sci., 4, 373-400 (1976).

McLusky, D.S. and M. Elliott: The Estuarine Ecosystem: Ecology, Threats and Management. Oxford University Press, Oxford (2004).

Menon, J.S. and S.V. Mahajan: Species-wise mercury accumulation in fish from Ulhas River Estuary and Thane Creek in the vicinity of Mumbai, India and its relation to the feeding habits of fish. Asian Fisheries Science, 24, 277-287 (2011).

Nagelkerken, I. and G. Van der Velde: A comparison of fish communities of subtidal seagrass beds and sandy seabeds in 13 marine embayments of a Caribbean island, based on species, families, size distribution and functional groups. J. Sea Res., 52, 127-147. (2004).

Nelson, J. S. and J. P. Martin: The fishes of Alberta. University of Alberta, Nature (1992).

Nikam, V.S., A. Kumar, K. Lalla and K. Gupta: Conservation of wetlands and mangroves in Thane creek and Ulhas River estuary, India. In Proceedings of Taal 2007: The $12^{\text {th }}$ World Lake Conference, pp. 1635-1642 (2008).

Patil, Y. and S. Ingle: Status of the Ulhas River with reference to water pollution at Badlapur City, Dist. Thane. Int. J. Sci. Res., 5, 453-455 (2016).
Psomadakis, P.N., H.B. Osmany and M. Moazzam: Field identification guide to the living marine resources of Pakistan. Food and Agriculture Organization of the United Nations, p. 436 (2015).

Rathod, S.D., N.N. Patil, G. Quadros and R.P. Athalye: Qualitative study of fin fish and shell fish fauna of Thane creek and Ulhas river estuary. In: Proceedings of the National Seminar on Creeks, Estuaries and Mangroves- Pollution and Conservation, pp. 135141 (2002).

Ray, G.C.: Connectivities of estuarine fishes to the coastal realm. Estuar. Coas. Shelf Sci., 64, 18-32 (2005).

Singare, P.U., M.P. Trivedi and R.M. Mishra: Sediment heavy metal contaminants in Vasai Creek of Mumbai: Pollution impacts. Amer. J. Chem., 2, 171-180 (2012).

Singare, P.U., M.P. Trivedi, R.M. Mishra and D.V. Dagli: Pollution impact assessment along Vasai Creek of Mumbai: Measurement of physico-chemical parameters. Int. Envir. Rev. 13, 220-243 (2012).

Singare, P.U.: Environmental assessment of some non-biodegradable solid wastes along Vasai Creek of Mumbai. Interdisci. Environ. Rev., 13, 118-126 (2012).

Singare, P.U.: Distribution and risk assessment of suspected endocrinedisrupting pesticides in creek water of Mumbai, India. Marine Pollu. Bull., 102, 72-83 (2016).

Sivadas, S., B. Ingole and M. Nanajkar: Temporal variability of macrofauna from a disturbed habitat in Zuari estuary, west coast of India. Environ. Monit. Assess., 173, 65-78 (2011).

Sreekanth, G.B., S.K. Chakraborty, A.K. Jaiswar and P.U. Zacharia: An inventory on the coastal finfish and shellfish species of Zuari estuary southwest coast of India. Indian J. Geo Marine Sci., 47, 945-958 (2018).

Wallace, J.H.: The estuarine fishes of the east coast of South Africa. Part 3. Reproduction. Investigational Report of the Oceanographic Research Institute, Durban, South Africa, 41, 1-48 (1975).

McDowall, R.M.: Is there such a thing as amphidromy? Micronesica, 30 3-14 (1997).

WoRMS Editorial Board. World Register of Marine Species. Available from http://www.marinespecies.org at VLIZ. Accessed 2019-11-19. 